ŽARKO KOBOEVIĆ, B.Sc.

E-mail: zarko.koboevic@unidu.hr

University of Dubrovnik, Maritime Department

Ćira Carića 4, 20000 Dubrovnik, Croatia

PAVAO KOMADINA, Ph.D.

E-mail: komadina@pfri.hr

University of Rijeka, Faculty of Maritime Studies

Studentska 2, 51000 Rijeka, Croatia

ŽELKO KURTELA, Ph.D.

E-mail: zeljko.kurtela@unidu.hr

University of Dubrovnik, Maritime Department

Ćira Carića 4, 20000 Dubrovnik, Croatia
Traffic and Environment (Ecology)

Review

Accepted: May 27, 2010

Approved: July 6, 2011

\title{
PROTECTION OF THE SEAS FROM POLLUTION BY VESSEL'S SEWAGE WITH REFERENCE TO LEGAL REGULATIONS
}

\begin{abstract}
This paper deals with the rules and regulations pertaining to the protection of the marine environment from the pollution by vessel's sewage. There is an international perspective on legal regulations dealing with this matter, but the sensitive marine environment has not been properly covered. Some maritime countries have set forth their own and more strict regulations to provide for a more efficient protection of their marine environments. Having compared the international legal regulations for the protection of the seas from pollution by vessel's sewage with the regulations of individual countries that have stricter regulations, a certain similarity has been noticed in some criteria, but also significant differences in some other criteria concerning allowed discharge of treated or untreated waste waters from the vessels. Amendments to the valid legal regulations and establishment of new rules pertaining to the marine environment are of particular importance in order to provide for a more effective protection of the seas from the increasing pollution from vessel's sewage preventing thus the negative influence onto marine organisms, human health and economy.
\end{abstract}

\section{KEY WORDS}

sea pollution, sewage, black water, faecal coliform bacteria, suspended solids, sewage treatment plant, convention

\section{INTRODUCTION}

Pollution of the marine environment is one of the major ecological problems nowadays.

Pollution is to be considered as the human direct or indirect introduction of matter or energy into the marine environment causing or liable to cause lethal consequences onto the living conditions of the marine and underwater flora and fauna, i.e. liable to jeopardize in general the marine living conditions as well as the human health and also to present a serious obstacle in maritime business, including fishing and other legal utilization of the seas and underwater world, to cause deterioration of the sea water quality and reduce attractiveness of the marine environment. A large number of national and international regulations have been set forth, the International Maritime Organisation - IMO - having played one of the major roles within the process. ${ }^{1}$

Besides the international regulations for the prevention of marine pollution from vessels, many maritime nations have set forth their own regulations not complying with the international regulations. The reason for this is the fact that the mentioned maritime nations have not ratified some of the international conventions pertaining to this matter, or have brought their own and stricter regulations for the prevention of marine pollution in general, including pollution from vessels ${ }^{2}$. Legal regulations, that have evolved and developed in the meantime, have contributed to slowing down the pollution of the seas by vessel's sewage. However, not withstanding the existing rules, some marine environments are still insufficiently protected and exposed to pollution. There is a series of disadvantages to the existing legal regulations that need remedy. Standardisation of the rules or their improvement may certainly lead to improvement in the protection of the marine environment from the pollution by vessel's sewage.

\section{THE TERM OF WASTE WATERS}

The term waste waters understands the used water whose physical, chemical and biological proper- 
ties have been changed to such an extent that it cannot be used for any other purpose without previous treatment, even when the water does not have to be clean.

The problem of waste waters on vessels is a specific problem, both due to the diversity and quantity of accumulated waste water as well as the procedures for their disposal, which are dictated by environmental regulations that are constantly getting stricter. Waste waters accumulated on vessels can be divided into bilge water and sanitary waste water. ${ }^{3}$

Bilge waters are categorised as industrial waste waters, and they are the result of accumulation of waters with high content of oil in the machinery spaces, accumulation of oil mixtures, sea water, fuel sludge, degreasing and washing chemicals.

"Black water" and "grey water" are generally considered as sanitary waste waters, as follows:

Sewage (black water)

1) discharges and other residues from all kinds of water closets (lavatories), urinals and toilets;

2) discharges from sinks, bathtubs and other installations in medical area (infirmary, hospital, etc.);

3) discharges from live stock spaces;

4) other waste waters, if they mix with the above mentioned discharges.

Waste water from laundry and accommodation (grey water)

1) waste waters from sinks, showers, bathtubs and their discharges except for the above mentioned water;

2) waste waters from laundries;

3) waste waters from washing provisions, kitchen appliances and food stores and restaurants. ${ }^{4}$

Storage time of the sewage accumulated on vessels varies and the water content in it is reduced (higher concentration) as consequence of reduced utilization of water for flushing sanitary units. ${ }^{5}$

Standards have been set regulating discharges of black and grey waters into the sea from vessels. Consequently, the vessels have been provided with equipment and installations for collection, storage, treatment and discharge of black and grey waters. Depending on the type of vessel, there is a series of various installations, equipment and systems for manipulation of these waters. Namely, on some vessels there are completely separate systems of grey and black waters that are being separately treated, while on some other vessels there are systems which after separate collection of grey and black waters, carry on the storage and further treatment in single storage tanks and equipment mixing and processing thus the black and grey waters together. The mixture of black and grey water actually becomes black water.

The type of waste water treatment equipment installed onboard vessels is also determined by legal regulations insofar as the parameters and limitations which the equipment must comply with have been prescribed by law. Certificates are being issued for such equipment as required by international regulations and standards and the certificates must be issued in compliance with them.

The following indicators are usually used to define properties of waste waters and treatment installations:

- Biochemical oxygen demand- BOD5 ${ }^{6}$

- Faecal coliforms ${ }^{7}$

- Suspended solids $^{8}$

Total residual chlorine, (an indicator only in some cases, e.g. "Alaska Waste Water Regulations").

\section{IMPACT OF SANITARY WASTE WATERS ON MARINE ENVIRONMENT}

Sewage (black water) contains various dangerous ingredients presenting a threat to human health, marine flora and fauna.

Sewage contains pathogenic organisms, viruses and bacteria that may cause human diseases, including salmonella, hepatitis A and E, gastrointestinal diseases and infections. Therefore, sewage is a threat to public health if it is discharged within the coastal areas utilized for recreation, such as swimming, diving and nautical tourism. It is also harmful to fishing and shellfish farming, since shellfish filtrate sea water retaining the particles and thus present a potential hazard of infecting the consumers of such shellfish or fish. Disintegration of faecal residues draws oxygen from the surrounding water, and if the discharged quantity is abundant the quantity of oxygen for fish and other marine organisms may be insufficient causing death of sea-life. Closed and shallow seas are exposed to greater risk under such circumstances.

Nutrients in sewage may cause algal overgrowth reducing the level of oxygen in the sea water, and consequently causing destruction of fish, corals, sea weed and other marine organisms. ${ }^{9}$

Sewage waste waters contain also chlorine, dioxin, ammonium or formaldehyde which are often used in sewage waste water treatment units as disinfectants prior to discharge outboard. ${ }^{10}$ Chlorine is extremely toxic even in small quantities and thus a serious hazard to marine live organisms and human health.

Metals (copper, lead, zinc, etc.) can also be found in sewage waste waters and in certain concentrations they are also toxic for living organisms.

"Grey water" can contain numerous elements polluting the marine environment, such as oil, grease, ammonium, phosphates, detergents, degreasers, pesticides, copper, lead, zinc, mercury and other heavy metals. 


\section{LEGAL REGULATIONS PERTAINING TO PROBLEMS WITH SANITARY WASTE WATER FROM VESSELS}

The problem of discharge and storage of sanitary waste waters from vessels, as well as equipment and certificates that the vessels must obtain in order to satisfy the prescribed standards, has been regulated by international rules and regulations as well as national regulations in maritime countries.

\subsection{INTERNATIONAL LEGAL REGULATIONS}

The most important international regulation pertaining to the problem of sea pollution from vessels is the International Convention for the Prevention of Pollution from Ships, 1973/78 (MARPOL 73/78) brought by $I M O^{11}$. MARPOL Convention sets standards and rules preventing pollution of the sea by oils, chemicals, harmful matter transported in any form of packages, sewage and garbage, emission of harmful gases and ballast. It aims at preventing or reducing marine pollution from ships, whether it occurred in an emergency situation or during regular ship operation. However, the discharge and pumping of sanitary waters are considered as regular ship operations. The Convention comprises a number of Annexes and Annex IV contains provisions regulating prevention and supervision of marine pollution by sewage waste waters from ships. Annex IV to the Convention refers to:

a) prohibiting or limiting discharge,

b) issuance of certificates and inspections,

c) equipment and supervision of discharge,

d) shore reception facilities.

MARPOL Annex IV is applicable to ships on international voyages that are 400 gross tonnage and more; or less than 400 gross tonnage when certified to carry more than 15 persons. ${ }^{12}$

According to MARPOL Annex IV, the discharge of sewage into the sea is prohibited, except when:

- the ship is discharging sewage which is not comminuted and disinfected at a distance of more than 12 nautical miles from the nearest land, provided that in any case, the sewage that has been stored in the holding tanks or sewage originating from spaces containing live animals, shall not be discharged instantaneously but at a moderate rate when the ship is en route and proceeding at not less than 4 knots, and that the maximum permissible discharge rate is $1 / 200,000$ of swept volume as follows: $D R m a x=0.00926 \times V \times D \times B$ where: Drmax is the maximum permissible discharge rate (m3/h); V is ship's average speed (knots) over the period; $D$ is Draft $(m)$; $B$ is Breadth $(m){ }^{13}$
- the ship is discharging comminuted and disinfected sewage using an approved system at a distance of more than 3 nautical miles from the nearest land;

- the ship is discharging sewage using an approved sewage treatment plant; the results of treatment effectiveness of the plant are laid down in the ship's International Sewage Pollution Prevention Certificate and the effluent shall not produce visible floating solids nor cause discolouration of the surrounding water. Such discharge is allowed when the ship is at any location.

The equipment for the supervision of discharge on board must include at least one of the following sewage systems:

- A sewage treatment plant which will be of a type approved by the Administration, taking into account the standards and test methods developed by the IMO.

- A sewage comminuting and disinfecting system approved by the Administration. Such system will be fitted with facilities to the satisfaction of the Administration, for the temporary storage of sewage when the ship is less than 3 nautical miles from the nearest land.

- A holding tank of the capacity to the satisfaction of the Administration for retention of all and which will have means to indicate visually the amount of its contents.

- In case the ship is equipped with sewage treatment plant, then the prescribed quality standards are effluent from sewage plant. ${ }^{14}$

To enable pipes of reception facilities to be connected with the ship's discharge pipeline, both lines will be fitted with a Standard Discharge Connection (standardised dimensions).

"International Sewage Pollution Prevention Certificate" will be issued to the ship by the Administration (or persons or organisations authorised by it), and after the general survey of the ship and installations according to the provisions set forth in Annex IV to the Convention. The certificate comprises general data on the ship, the sewage system and type of sewage plant, as well as the results of tests made in compliance with the stated restrictions.

Government of each nation that has adopted the Convention is liable to ensure installation of sewage reception facilities in ports and terminals.

Although they do not address the matter to the extent and precision of MARPOL, there are several other international sources dealing with prevention from marine pollution by vessel's sewage:

- The United Nations Convention on Law of the Sea $(1982)^{15}$

The Convention on Law of the Sea gives guidance to maritime states to practice co-operation and among other things to adjust implementation of 
Table 1 - Sewage water effluent standard after treatment plants and prior to discharge from the ship into the sea, as per MARPOL Annex IV

\begin{tabular}{|c|c|c|c|c|}
\hline & $\begin{array}{c}\text { Faecal coliforms } \\
/ 100 \mathrm{ml} \\
\end{array}$ & $\begin{array}{c}\text { Suspended solids } \\
\mathrm{mg} / \mathrm{l}\end{array}$ & $\begin{array}{c}\text { Biochemical oxygen demand ( BOD5) } \\
\mathrm{mg} / \mathrm{I}\end{array}$ & $\mathrm{pH}$ \\
\hline $\begin{array}{l}\text { Treatment plant installed } \\
\text { before 1st Jan } 2010\end{array}$ & 250 & $50(100) *$ & 50 & -- \\
\hline $\begin{array}{l}\text { Treatment plant installed } \\
\text { after 1st Jan } 2010\end{array}$ & 100 & 35 & $\begin{array}{c}25 \\
\text { \& Chemical oxygen demand - } 125\end{array}$ & $6.0-8.5$ \\
\hline
\end{tabular}

Remark: *50 mg/l if plant tested ashore; $100 \mathrm{mg} / \mathrm{I}$ if plant tested onboard

Table 2 - Sewage water effluent standard prior to discharge, as per CRS

\begin{tabular}{||c|c|c|c||}
\hline $\begin{array}{c}\text { Faecal coliforms } \\
/ 100 \mathrm{ml}\end{array}$ & $\begin{array}{c}\text { Suspended solids } \\
\mathrm{mg} / \mathrm{l}\end{array}$ & $\begin{array}{c}\text { Biochemical oxygen demand (BOD5) } \\
\mathrm{mg} / \mathrm{l}\end{array}$ & $\begin{array}{c}\text { Chlorine } \\
\mathrm{mg} / \mathrm{l}\end{array}$ \\
\hline \hline 100 & $35 *$ & $25 * *$ & $6,0-8,5$ \\
\hline
\end{tabular}

Remark:

*35 mg/l if plant tested ashore; $x+35 \mathrm{mg} / \mathrm{l}$ if plant tested onboard, $x$-suspended solids in water for plant washing (mg/l)

** and chemical oxygen demand $-125 \mathrm{mg} / \mathrm{l}$

rights and obligations with respect to the protection and preservation of the marine environment.

- Convention for Protection of the Mediterranean Sea against Pollution, adopted in Barcelona in 1976

The major obligation of the signatories to the Convention is the implementation of all the necessary measures for prevention, reduction and suppression of pollution as well as protection and development of the marine environment. When amending the Mediterranean system in 1995 a revised and amended convention was adopted under the title Convention for Protection of the Marine Environment and the Coastal Region of the Mediterranean $^{16}$.

\subsection{LEGAL REGULATIONS IN THE REPUBLIC OF CROATIA}

As far as marine pollution from ships is concerned, most of the regulations are the result of adopting relevant international conventions under the International Maritime Organisation, but also of the implementation of the European Union rules and regulations ${ }^{17}$.

The Republic of Croatia has adopted the MARPOL Convention $^{18}$

In the Republic of Croatia, the problem of protection of the sea from the discharge of sewage has been regulated by a series of laws and regulations, such as: - "Maritime Law"19,

- "Environmental Protection Act" ${ }^{20}$,

- "Regulations on Protection of Marine Environment in the Ecological-Fishing Zone of the Republic of Croatia".

The rules for building and supervision of ships of the Croatian Register of Shipping (CRS) ${ }^{21}$, like many other classification societies, are based on the stipulations set forth in IMO Conventions and Resolutions
(MARPOL and SOLAS). Consequently, the equipment, installations and certificates for the treatment of sewage waste waters comply with the MARPOL Convention. CRS also sets standards on the restriction of chlorine, if it is used as disinfectant of sewage waste waters. The total residual chlorine in the water discharged into the sea must not exceed $0.5 \mathrm{mg} / \mathrm{I}^{22}$.

\subsection{LEGAL REGULATIONS IN THE EU}

Member states of the EU are signatories of MARPOL Convention, pursuant to which they implement regulations and restrictions pertaining to discharge of sewage from vessels.

The European Environment Agency $(E E A)^{23}$ is the most important of all EU institutions and bodies for monitoring and inspection of pollution.

The EU has incorporated many documents, strategic instruments, initiatives and action plans in protection and preservation of the marine environment as a whole, and especially in protection of the Mediterranean.

One of the most important documents related to the waste waters from vessels is Directive 2007/71/ $E C^{24}$ of the European Parliament and the Council regarding port reception facilities for sewage from ships and cargo residues. It has been implemented as of 17th September 2009 and according to it the ships are obliged to advise the port of call on the condition of sewage waste waters on board, i.e. the master must advise the port authorities at the latest 24 hours prior to arrival by filling in the required form. The ships are required to pump out their sewage waters into port reception facilities if the ship cannot discharge sewage waters in compliance with MARPOL or if the ship's capacities are not sufficient to keep the sewage waste waters onboard until the next port of call, including the sewage collected until that next port of call. The 
purpose of this regulation is to reduce discharge of sewage waters into the sea, in particular the illegal discharges within $3 \mathrm{~nm}$ from shore. It does not apply to boats and yachts accommodating fewer than 12 passengers, nor to fishing boats.

Directive 2000/59EC ${ }^{25}$ was brought to ensure joint ecological standards for private facilities (for liquid and crude waste from ships and cargo residues) in all ports within the EU. Environmental protection requirements should apply to all ships regardless of the flag. The purpose is to reduce the quantity of sewage discharged.

The Mediterranean Strategy for Sustainable Development (MSSD) ${ }^{26}$ was brought in order to adjust the international standards with the regional and national development strategies, in particular having in mind the reduction of unsustainable barrier between the developed Mediterranean countries and the developing countries. The strategy is applied in the Mediterranean countries that are members of the EU, but also the potential members. Indirectly it can be applied onto the Mediterranean countries neighbouring the EU. Seven priority fields of action have been determined, that are the most endangered. Sustainable sea management, coastal management and marine resources are one of them.

Directive $2005 / 35 / \mathrm{EZ}^{27}$ of the European Parliament and the Council dated 7th September 2005 on pollution from ships and introduction of fines for breaches was brought with the aim of incorporating international standards on pollution from ships into the EU legislation and of ensuring individual responsibility and penalties for discharge from ships.

Directive 2099/2002/EZ ${ }^{28}$ of the European Parliament and the Council dated 5th November 2005 instituting the Committee of Safe Seas and Prevention from Pollution from Ships (COSS) and changing the Regulations on Safety on Sea and Prevention from Pollution from Ships, was brought to improve the implementation of EU regulations on the safety at the sea, prevention from pollution from ships and living and working conditions onboard.

\subsection{LEGAL REGULATIONS IN THE USA}

The USA are not signatory of the MARPOL Convention Annex $\mathrm{IV}^{29}$, but they have their own legal regulations covering discharge of sewage waste waters. In conformity with the federal laws grey waste waters are not defined as pollutant and there are no special legal regulations defining the standards for discharge of grey water (similar to MARPOL Convention).

Major federal agencies having the jurisdiction over the issue of sewage waste waters are: the US Coast Guard, ${ }^{30}$ Environmental Protection Agency (EPA) ${ }^{31}$ and the Department of Justice ${ }^{32}$.
Clean Water Act Section $312^{33}$ pertains to the standards of discharge from Marine Sanitation Device $(M S D)^{34}$, as well as the procedure for determining No Discharge Zones (NDZ) ${ }^{35}$, for ship's sewage in the zones where any discharge of sewage is prohibited. Presently there are a total 67 No Discharge Zones in the USA ${ }^{36}$.

Generally speaking, Section 312 is being implemented in co-operation with the U.S. Coast Guard and Environmental Protection Agency. Pursuant to this Section, marine sanitation devices must be installed (MSD), approved and attested by the U.S. Coast Guard, on all commercial and recreational vessels equipped with toilets. These devices must satisfy EPA standards.

Nevertheless, Section 312 is not implemented within $3 \mathrm{~nm}$ from shore, where discharge of untreated sewage waste water is prohibited.

The U.S. Coast Guard recognizes and approves 3 types of Marine Sanitation Device (MSD) which are according to 33 CFR Part 15937.

- Type I MSD - are flow-through treatment devices that commonly use maceration and disinfection for treatment of sewage. Type I devices may be used only on vessels less than $19.7 \mathrm{~m}$ (65 feet). EPA's performance standard for effluent are max 1000 faecal coliforms per $100 \mathrm{ml}$ of water with no visible floating solids.

- Type II MSD -are also flow-through treatment devices, generally employing biological treatment and disinfection. Some of these devices use maceration and disinfection. Type II MSD may be used on vessels of any size. EPA's performance standard is an effluent with a faecal coliform count not to exceed 200 per $100 \mathrm{ml}$ of water and total suspended solids no greater than $150 \mathrm{mg}$ per litre of water.

- Type III MSD - are holding tanks, where sewage is stored until it can be properly disposed of at a shore-side pump-out facility or out at the sea (beyond 3 miles from shore). Type III MSD may be used on vessels of any size. However, Type II MSD may be equipped with installed holding tanks which can be used to store treated sewage until reaching a shore-side pump-out facility or discharged overboard when vessel is beyond 3 miles from land.

The U.S. Coast Guard also carries out inspections of foreign ships calling USA waters, and if the ships have a valid International Sewage Pollution Prevention Certificate (ISPPC) in compliance with MARPOL Annex IV, and provided the device is in working order, they accept that the marine sanitation device is in compliance with stipulation 33 CFR 159. ${ }^{38}$

Besides the above mentioned federal regulations in the USA, there are separate regulations in individual states within the USA, each having its own laws and regulations. Namely, the state of Alaska is particularly known to have brought regulations and restrictions which are by far the strictest in the USA. The standards 
Table 3 - Vessel effluent standard comparison in the USA

\begin{tabular}{|c|c|c|c|c|c|}
\hline Device type & Faecal coliforms & Suspended solids & $\begin{array}{l}\text { Biochemical oxygen } \\
\text { demand ( BOD5) }\end{array}$ & $\mathrm{pH}$ & Chlorine \\
\hline Type I MSD & $1000 \mathrm{col} / 100 \mathrm{ml}$ & $\begin{array}{l}\text { With no visible } \\
\text { floating solids }\end{array}$ & - & $\ldots$ & -- \\
\hline Type II MSD & $200 \mathrm{col} / 100 \mathrm{ml}$ & $150 \mathrm{mg} / 100 \mathrm{ml}$ & -- & -- & -ב--- \\
\hline $\begin{array}{l}\text { Alaska Standards for } \\
\text { Continuous Discharge } \\
\text { Blackwater from large } \\
\text { commercial vessels }^{1}\end{array}$ & $20 \mathrm{col} / 100 \mathrm{ml}$ & $\begin{array}{l}30 \mathrm{mg} / \mathrm{I} \text { monthly average } \\
45 \mathrm{mg} / \mathrm{I} \text { weekly average. }\end{array}$ & $\begin{array}{l}30 \mathrm{mg} / \mathrm{I} \text { monthly average } \\
45 \mathrm{mg} / \mathrm{I} \text { weekly average. }\end{array}$ & $6.0-9.0$ & $10 \mathrm{mg} / \mathrm{l}$ \\
\hline $\begin{array}{l}\text { Alaska Standards greywa- } \\
\text { ter and blackwater from } \\
\text { other vessels }{ }^{2}\end{array}$ & $200 \mathrm{col} / 100 \mathrm{ml}$ & $150 \mathrm{mg} / \mathrm{l}$ & 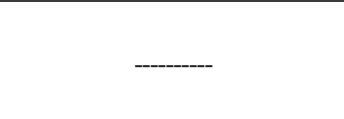 & 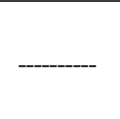 & 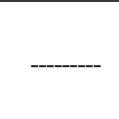 \\
\hline
\end{tabular}

Remarks:

1 Code of Federal Regulations (CFR) 159.309

2 Alaska Regulations Section 46.03.463, Subsections b and c

Source: Maine Government (www.maine.gov/dep/b/wq/topic/vessels/effluentchart.pdf) (27.02. 2010)

Table 4 - Standards for discharge of sewage waste waters in Australian waters

\begin{tabular}{|c|c|c|}
\hline Vessel/Voyage type/Area & Sub-Category & Discharge Conditions \\
\hline $\begin{array}{l}\text { Vessels on international voyages Comminuted and } \\
\text { disinfected sewage using an approved system }\end{array}$ & $>3 \mathrm{~nm}$ from nearest land. & $\begin{array}{l}\text { Vessels on international voyages } \\
\text { Sewage stored in holding tanks } \\
\text { (untreated and treated sewage) }\end{array}$ \\
\hline > 12 nm from nearest land; and & $\begin{array}{l}\text { discharged at a mod- } \\
\text { erate rate*; and }\end{array}$ & $\begin{array}{l}\text { ship proceeding en route at a } \\
\text { speed of at least } 4 \text { knots. }\end{array}$ \\
\hline $\begin{array}{l}\text { * The rate of discharge must be approved by the } \\
\text { Administration. Vessels on international voyages } \\
\text { Treated sewage effluent discharged through an } \\
\text { IMO approved sewage treatment plant (STP) } \\
\text { Also integrated system where the STP includes }\end{array}$ & grey water input & food processing input. \\
\hline $\begin{array}{l}\text { Effluent not to produce visible floating solids nor } \\
\text { cause discolouration of the surrounding water. }\end{array}$ & $\begin{array}{l}\text { When within port limits, } \\
\text { check with port authority as } \\
\text { permission may be required }\end{array}$ & $\begin{array}{l}\text { All vessels should ensure } \\
\text { that the STP is operating } \\
\text { at optimum performance } \\
\text { when in Australian waters }\end{array}$ \\
\hline $\begin{array}{l}\text { Food or biological waste removed from filtration } \\
\text { unit is prohibited from discharge within } 12 \mathrm{~nm} \\
\text { from land (Australian Quarantine requirements) }\end{array}$ & Vessels on domestic voyages & $\begin{array}{l}\text { Recommended to comply } \\
\text { with MARPOL Annex IV }\end{array}$ \\
\hline Local laws may prohibit discharges in ports & $\begin{array}{l}\text { Great Barrier Reef Marine } \\
\text { Park Vessels on International } \\
\text { voyages to and continuing } \\
\text { in Australian waters }\end{array}$ & All sewage discharges \\
\hline $\begin{array}{l}\text { In accordance with Annex IV requirements and } \\
\text { where applicable with any additional restrictions } \\
\text { imposed as conditions of a GBRMP permit }\end{array}$ & $\begin{array}{l}\text { Great Barrier Reef Marine } \\
\text { Park Vessels on domestic voy- } \\
\text { ages All sewage discharges }\end{array}$ & $\begin{array}{l}\text { Recommended to comply } \\
\text { with MARPOL Annex IV }\end{array}$ \\
\hline
\end{tabular}

Source: AMSA, Australian Government, (http://www.amsa.gov.au/Marine_Environment_Protection/Protection_of_Pollution_from_Ships/ Discharge_Standards.asp) (26.02.2010)

for discharge from sewage treatment plants are given under: 33 CFR Part 159 Subpart $E^{39}$, and it refers to cruise ships.

Pursuant to this law, discharges of treated water from marine sanitation devices are allowed when the ship speed is 6 knots or more, and the distance to the nearest land is over one $\mathrm{nm}$, and also the quality of water discharged satisfies the standard ${ }^{40}$ for discharge of such water, as shown in Table 3.

\subsection{LEGAL REGULATIONS IN AUSTRALIA}

Australia is a signatory of MARPOL Convention with all its addenda and all stipulations from MARPOL Annex IV are applied. Inspections of ships calling the Australian waters are performed by the Australian Maritime Safety Authority (AMSA) ${ }^{41}$.

Besides the stipulations in MARPOL there are also regulations covering separate regions (first of all 
Table 5 - Comparison of provisions for discharge and standards for discharge of sewage waters worldwide

\begin{tabular}{|c|c|c|c|c|}
\hline $\begin{array}{l}\text { Region } \\
\text { (State) }\end{array}$ & Area & Ships & Allowed discharge & Discharge criteria \\
\hline \multirow{3}{*}{$\begin{array}{l}\text { States } \\
\text { signatories } \\
\text { of MARPOL } \\
\text { Annex IV, } \\
\text { EU countries, } \\
\text { Croatia, } \\
\text { Australia }\end{array}$} & \multirow[b]{3}{*}{$\begin{array}{l}\text { International } \\
\text { navigation }\end{array}$} & \multirow{3}{*}{$\begin{array}{l}\geq 400 \text { gross } \\
\text { tonnage } \\
\geq 15 \text { persons }\end{array}$} & $\begin{array}{l}>12 \mathrm{~nm} \text { from } \\
\text { nearest land }\end{array}$ & $\begin{array}{l}\text { - untreated faecal waters discharge at } \\
\text { speed }>4 \mathrm{kn} \text { and discharged quantity } \\
\text { Drmax }=0,00926 \times \mathrm{V} \times \mathrm{DxB}\end{array}$ \\
\hline & & & $\begin{array}{l}>3 \mathrm{~nm} \text { from } \\
\text { nearest land }\end{array}$ & $\begin{array}{l}\text { - sewage effluent and disinfected in IMO } \\
\text { approved plant }\end{array}$ \\
\hline & & & $<3 \mathrm{~nm}$ from land & $\begin{array}{l}\text { - discharge of water from plant with stan- } \\
\text { dards: } \\
\text { - Qtty of bacteria }<100 / 100 \mathrm{ml} \\
\text { - suspend. matter }<35 \mathrm{mg} / \mathrm{l} \\
\text { - BPK5 }<25 \mathrm{mg} / \mathrm{l} \\
\text { - pH } 6,0-8,5 \\
\text { - (chlorine }<0,5 \mathrm{mg} / \mathrm{l} \text { ) }\end{array}$ \\
\hline \multirow{3}{*}{ USA } & \multirow{3}{*}{$\begin{array}{l}\text { International } \\
\text { and domes- } \\
\text { tic navigation }\end{array}$} & $\begin{array}{l}\text { Ships }<19.7 m \\
\text { Type I MSD }\end{array}$ & $<3 \mathrm{~nm}$ from land & $\begin{array}{l}\text { - Qtty of bacteria }<1000 / 100 m l \\
\text { - and without visible solids }\end{array}$ \\
\hline & & $\begin{array}{l}\text { All ships } \\
\text { Type II MSD }\end{array}$ & $<3 \mathrm{~nm}$ from land & $\begin{array}{l}\text { - Qtty of bacteria }<200 / 100 \mathrm{ml} \\
\text { - suspend. matter }<150 \mathrm{mg} / \mathrm{l}\end{array}$ \\
\hline & & $\begin{array}{l}\text { All ships } \\
\text { Type III MSD }\end{array}$ & $\begin{array}{l}>3 \mathrm{~nm} \text { from } \\
\text { nearest land }\end{array}$ & - untreated faecal waters \\
\hline \multirow{3}{*}{ Alaska (USA) } & \multirow{3}{*}{$\begin{array}{l}\text { International } \\
\text { and domes- } \\
\text { tic navigation }\end{array}$} & $\begin{array}{l}\text { Ships }<19.7 m \\
\text { Type I MSD }\end{array}$ & $<3 \mathrm{~nm}$ from land & $\begin{array}{l}\text { - Qtty of bacteria }<1000 / 100 \mathrm{ml} \\
\text { - and without visible solids }\end{array}$ \\
\hline & & $\begin{array}{l}\text { All ships } \\
\text { Type II MSD }\end{array}$ & $\begin{array}{l}>1 \mathrm{~nm} \text { from } \\
\text { nearest land }\end{array}$ & $\begin{array}{l}\text { - Ship's at speed }>6 \mathrm{kn} \\
\text { - Qtty of bacteria }<20 / 100 \mathrm{ml} \\
\text { - suspend.matter }<30(45) \mathrm{mg} / \mathrm{l} \\
\text { - BPK5 }<30(45) \mathrm{mg} / \mathrm{l} \\
\text { - pH } 6,0-9,0 \\
\text { - }(\text { chlorine }<10 \mathrm{mg} / \mathrm{l})\end{array}$ \\
\hline & & $\begin{array}{l}\text { All ships } \\
\text { Type III MSD }\end{array}$ & $\begin{array}{l}>3 \mathrm{~nm} \text { from } \\
\text { nearest land }\end{array}$ & - untreated faecal waters \\
\hline \multirow{5}{*}{$\begin{array}{l}\text { Queensland, } \\
\text { Great Bar- } \\
\text { rier Reef } \\
\text { Marine Park } \\
\text { (Australia) }\end{array}$} & \multirow{5}{*}{$\begin{array}{l}\text { Domestic } \\
\text { navigation }\end{array}$} & \multirow{2}{*}{$\begin{array}{l}\text { Small ships, rec- } \\
\text { reational, fishing, } \\
\text { and ships flying } \\
\text { Australian flag } \\
\text { without installed } \\
\text { sewage treat- } \\
\text { ment plant }\end{array}$} & \multicolumn{2}{|c|}{$\begin{array}{l}>16 \text { persons } \\
\text { discharge of untreated sewage waters not allowed any- } \\
\text { where in Queensland waters (apply MARPOL stipulations) }\end{array}$} \\
\hline & & & \multicolumn{2}{|c|}{$\begin{array}{l}7-15 \text { persons } \\
\text { discharge of untreated sewage waters not allowed within } \\
1 \mathrm{~nm}(1,852 \mathrm{~m}) \text { from reef, island or nearest land }\end{array}$} \\
\hline & & \multirow{3}{*}{$\begin{array}{l}\text { Small ships, rec- } \\
\text { reational, fishing, } \\
\text { and ships flying } \\
\text { Australian flag } \\
\text { with installed sew- } \\
\text { age treatment plant }\end{array}$} & $\begin{array}{l}\text { Outside ports, chan- } \\
\text { nels and marinas }\end{array}$ & $\begin{array}{l}\text { Discharge category A: } \\
\text { - Qtty of bacteria }<250 / 100 \mathrm{ml} \\
\text { - suspend. matter }<50 \mathrm{mg} / \mathrm{l} \\
\text { - BPK5 }<50 \mathrm{mg} / \mathrm{l}\end{array}$ \\
\hline & & & $\begin{array}{l}>700 \text { m from reef, } \\
\text { aquaculture or } \\
\text { man overboard }\end{array}$ & $\begin{array}{l}\text { Discharge category B: } \\
\text { - Qtty of bacteria }<150 / 100 \mathrm{ml} \\
\text { - suspend. matter }<50 \mathrm{mg} / \mathrm{l}\end{array}$ \\
\hline & & & $\begin{array}{l}>1 / 2 \mathrm{~nm} \text { from } \\
\text { reef, aquaculture } \\
\text { or man overboard }\end{array}$ & $\begin{array}{l}\text { Discharge category C: } \\
\text { - Qtty of bacteria }<150 / 100 \mathrm{ml}\end{array}$ \\
\hline
\end{tabular}

the Great Barier Reef, or the state of Queensland), which have been brought both on state and federal level. As of 1st January 2010 there is a new regulation valid in the state of Queensland, focusing onto vessels with larger capacities of sewage waste waters, i.e. all vessels carrying more than 6 persons. Consequently, this regulation is being implemented not only on the ships as stated in MARPOL, but also on all other vessels: commercial, recreational and fishing boats. ${ }^{42}$

Pursuant to these regulations discharge of untreated sewage waters is strictly prohibited in the waters of Queensland for all ships carrying over 16 persons, and for ships carrying from 7-15 persons it is prohibited to discharge untreated sewage water within $1 \mathrm{~nm}$ from the nearest land, coral reefs or in case of men over- 
board (here it refers to swimmers, fishermen or sportsmen practicing various activities in the sea). Table 4 shows the standards for discharge of sewage waste waters in Australian waters.

\section{CONCLUSION}

Pollution of marine environment by sewage waters has been increasing due to pollution from land and pollution from vessels due to increased seaborne trade. The international community has set forth legal regulations covering this issue in order to properly protect not only the marine environment but also the human health, which is also often exposed to hazards due to pollution from sewage waste waters. Nevertheless, the sea has still remained a fragile area exposed to various pollutants and risks. The reasons for still insufficient effectiveness in protection and preservation of the seas are complex and numerous. Besides the economical, political and other differences between the states and the problem of limited financial resources, we can point out the still low political priority being given to the environment as well as the lack of public awareness on the problem of environmental protection in some countries.

Consequently, besides the international regulations, some states have set forth their own regulations which are stricter, aiming to better protect their particularly sensitive areas, since the internationally recognised regulations have their disadvantages and there is still room for improvement.

For example, MARPOL Annex IV does not refer to vessels carrying fewer than 15 persons, nor to ships in domestic navigation, ferries for example being a good example of the category presenting risk from marine pollution from sewage.

Furthermore, stipulation 11.2 of Annex IV does not apply to ships owned by the state or ships arriving from other countries while they are still in the relevant country waters, if requirements prescribed by that country are less strict. Thus, the ships can manipulate with weaknesses of the state legislations of some countries.

The quantity of sewage produced onboard is directly connected to the number of persons onboard, and not on the size of the vessel. Pollution by sewage waste waters from a larger number of smaller vessels that are not subject to these legal regulations may be more abundant in quantity than from larger vessels that have installed and utilize sewage treatment plants as prescribed by law.

Pollution by vessel's sewage presents a particular problem to tourism, especially when tourism is based on various water activities such as swimming or nautical tourism. In Croatia, as well as in most of the countries signatories of MARPOL Convention, boats and yachts carrying fewer than 15 persons have not been regulated by legal regulations with respect to discharge of sewage waters into the sea, presenting thus a risk from pollution of the sea surface layer by sewage in coastal tourist areas, on beaches and in bays, during the summer months, when boat and yacht traffic is increased. Such pollution may not inflict serious damage to the eco-system, but it will certainly, through the visual effect of the sea surface along beaches and the shore, leave negative effect on tourism.

In the Baltic Sea, the problem of introducing nutrients into the sea by discharge of sewage from shore and off-board is becoming one of the most actual problems of this Sea. The Baltic countries have already started their initiative towards the international community and IMO for adoption of new amendments as obligatory instruments, referring to the establishment of "special zones" to prevent pollution from sewage waste waters and declaring the Baltic Sea as one of such zones. ${ }^{43}$ The adoption of amendment to Annex IV, namely, is currently being considered, in which, besides the "special zones" for protection from pollution from sewage waste waters, additional standards would be set for the quality of discharge from sewage treatment plants only for passenger ships carrying more than 12 passengers and sailing within the "special zones". This amendment would provide for reduction of nutrients in sewage waters, such as nitrogen and phosphorus, prior to discharge into the sea.

Aiming at better protection of the seas from the pollution from sewage waste waters, it is still necessary to bring amendments to the existing legal regulations both at national and international level.

\section{ŽARKO KOBOEVIĆ, dipl. ing.}

E-mail: zarko.koboevic@unidu.hr

Sveučilište u Dubrovniku, Pomorski odjel

Ćira Carića 4, 20000 Dubrovnik, Hrvatska

\section{Dr. Sc. PAVAO KOMADINA}

E-mail: komadina@pfri.hr

Sveučilište u Rijeci, Pomorski fakultet

Studentska 2, 51000 Rijeka, Hrvatska

Dr. Sc. ŽELKKO KURTELA

E-mail: zeljko.kurtela@unidu.hr

Sveučilište u Dubrovniku, Pomorski odjel

Ćira Carića 4, 20000 Dubrovnik, Hrvatska

\section{SAŽETAK}

\section{ZAŠTITA MORA OD ONEČIŠĆENJA SANITARNIM OTPADNIM VODAMA S PLOVNIH OBJEKATA, S OSVRTOM NA PRAVNU REGULATIVU}

Onečišćenje morskog okoliša sanitarnim otpadnim vodama s kopna is plovila predstavlja jedan od ozbiljnih problema današnjice. Pravna regulativa koja regulira taj problem postoji na međunarodnom nivou, ali ne štiti dovoljno dobro osjetljiva morska područja. Neke obalne države imaju svoje strože propise zbog efikasnije zaštite svojih osjetljivih 
morskih prostora. Usporedbom međunarodne zakonske regulative za zaštitu mora od zagađenja fekalnim otpadnim vodama s regulativom pojedinih zemalja koje imaju strožu regulativu, mogu se uočiti sličnosti u nekim kriterijima, ali i velike razlike u drugim kriterijima za dozvoljeno ispuštanje tretirane ili netretirane otpadne fekalne vode s brodova. Mijenjanje postojeće zakonske regulative $i$ donošenje novih propisa koji se odnose na neka od morskih područja posebno je važno kako bi se efikasnije štitilo more od sve većeg zagađenja fekalnim otpadnim vodama s plovila i tako spriječio negativan utjecaj na morske organizme, zdravlje ljudi i gospodarstvo.

\section{KLUČNE RIJEČI}

zagađenje mora, fekalne otpadne vode, crne vode, koliformne bakterije, suspendirane tvari, uređaj za tretiranje fekalnih otpadnih voda, konvencija.

\section{REFERENCES}

1. In 1948 at the United Nations Conference the International Governmental Maritime Consultative Organisation - IMCO was constituted, and in 1982 it was renamed into International Maritime Organisation IMO. The aims of the organisation are improvement of international maritime traffic safety, protection of the sea from pollution, research and exploitation of the underwater resources, proper regulation of the international seafaring and technical assistance to shipping in developing countries. Within the IMO the crucial role in setting international standards against marine pollution was played by its Marine Environment Protection Committee (MEPC).

2. The term vessel refers to a water craft designed for plying the seas. The water craft can be a ship, naval ship, yacht or boat. - Maritime Law (Official Gazette, No. 181 / 04), Article 5, para. 3.

3. M. Bupić, L. Milić: Ship's Sewage Treatment Plant With Reference to Venting and Clarification Procedures, Naše More 45 (3-4,5-6), Dubrovnik 1998.

4. Source: Croatian Register, Rules for Statutory Certification of Marine Vessels, Part 22 - Prevention of Pollution, 2009, p.33.

5. S. Hanninen, J. Sassi, Estimated Nutrient Load from Waste Waters originating from Ships in the Baltic Area - updated 2009, Research Report VTT-R-07396-08, VTT Technical Research Centre of Finland,VTT, 2009, p.22.

6. The quantity of oxygen that the organic matter in sewage spends on its metabolism within five days.

7. Bacteria the number of which is generally used to indicate presence of sewage waters and microorganisms that may be harmful to human health. Coliform is a specie of bacteria living in human intestines. The number of coliform bacteria is easy to determine by lab tests, which indicate the level of sewage present in the waste water.

8. Geometrical average concentration of suspended matter in waste water was measured in 40 samples. Suspended matter is usually invisible, but in time they can cause turbidity.
9. According to UK Marine SACs Project, Possible effects of high concentration of sewage entering the marine environment from recreational craft, (http://www. ukmarinesac.org.uk/activities/ports/ph6_2_3.htm) (14.02.2010)

10. A.West, Marine Pollution from Vessel Sewage in Queensland, Australian and New Zealand Maritime Law Journal, Vol. 18, Murdoch University, Murdoch 2004 p.128.

11. MARPOL Convention, (Official Gazette - International Conventions, No. 1/92, 4/05). Text of the Convention in Croatian to be found in: The International Convention on Prevention from Marine Pollution by Ships, Maritime Journal, Ministry of the Sea, Tourism, Traffic and Development.

12. Under "international navigation" it is to be understood navigation from the country applying this Convention until the port outside that country or vice versa. The term "person" refers to crew members and passengers.

13. According to IMO Resolution MPC.157(55) Recommendation on Standards for the Rate of Discharge of Untreated Sewage from Ships, adopted on $13^{\text {th }}$ October 2006, and MEPC.164(56) adopted and implemented as of $1^{\text {st }}$ December 2008.

14. IMO Resolution MEPC.159(55) Revised Guidelines on Implementation of Effluent Standards and Performance Tests for Sewage Treatment Plants, adopted on $13^{\text {th }}$ October 2006, is implemented on plants installed as of $1^{\text {st }}$ January 2010; this Resolution replaced the Resolution MEPC.2(6) Recommendation on International Effluent Standards and Guidelines for Performance Tests for Sewage Treatment Plants, adopted on $3^{\text {rd }}$ December 1976 and which had set somewhat lower standards.

15. The Convention came into force on $16^{\text {th }}$ November 1994. On the basis of notification of succession Croatia became a party to the Convention, see Off. Gazette MU 9/00.

16. Revised and amended Barcelona Convention from 1995 was ratified by Croatia (Official Gazette MU 17/98).

17. Source: D. Ćorić, S. Debeljak-Rukavina, Protection of Marine Environment in Protected Ecological-Fishing Zone of the Republic of Croatia, Almanac of the Faculty of Law at the University of Rijeka Vol. 29, No. 2, Rijeka 2008, p. 959.

18. MAROPL (Official Gazette - International Conventions, No. 4 / 05)

19. Maritime Law (Official Gazette, No. 181/04, 76/07) Art. 41, para. 1: "During navigation through Croatian economic zone all vessels must comply with the generally accepted international regulations and standards as well as Croatian regulations on protection from marine and air pollution by ships and pollution caused by sinking or underwater activities."

20. The Environmental Protection Act (Official Gazette, No. $110 / 07$ ), Art. 24, para.1: "Marine protection encompasses measures for protection of the sea including the marine ecosystem and coastal area as a single unit, prevention of harmful activities in the marine ecosystem, prevention of marine pollution from air, land, vessels and other polluters due to maritime traffic, in- 
cluding also pollution caused by discharges from ships or from aircraft aiming at sinking or incineration at the sea, as well as trans-frontier pollution, and prevention of pollution due to larger accidents and remedy of their consequences."

21. CRS is an independent, non-profit, public institution dedicated to public welfare performing: classification of ships; statutory certification of ships on behalf of the national maritime administrations; statutory certification of marine equipment; statutory certification of recreational craft; certification of quality management system. The mission of CRS, concerning classification and statutory certification, is to promote the highest internationally adopted standards with respect to safety and protection of life and property at the sea and inland waterways, as well as protection of marine and inland waterway environments. The present status of CRS is defined by the Law on Croatian Register of Shipping (Official Gazette, No. 81/96) and CRS Statute.

22. Croatian Register, Rules for Statutory Certification of Ships, Part 22 - Prevention from Pollution, 2009, p.33.

23. All member countries of the EU are its members as well, but other countries can also become members. The Agency is dedicated to formation of reporting and European environment monitoring networks.

24. (Commission Directive $2007 / 71 / \mathrm{EC}$ of $13^{\text {th }}$ December 2007 amending Annex II of Directive 2000/59/EC of the European Parliament and the Council on port reception facilities for ship-generated waste and cargo residues) (http://eurlex.europa.eu/LexUriServ/LexUriServ.do?uri=0J:L:2007:329:0033:0036:EN:PDF) (20.02.2010)

25. (Directive 2000/59/EC of the European Parliament and of the Council of $27^{\text {th }}$ November 2000 on port reception facilities for ship-generated waste and cargo residues - Commission declaration) (http://eur-lex.europa.eu/LexUriServ/LexUriServ.do?uri=CELEX:32000 L0059:EN:HTML) (20.02.2010)

26. Decision (21 Mediterranean and European Union countries) on the development of the Mediterranean strategy for sustainable development was brought on $12^{\text {th }}$ Conference of the parties to the Barcelona Convention in Monaco, in November 2001, and the initiative was supported at the $2^{\text {nd }}$ Euro-Mediterranean Ministerial Conference on Environment in Athens in July 2002.

27. (Directive 2005/35/EC of the European Parliament and of the Council dated $7^{\text {th }}$ September 2005 on ship-source pollution and on the introduction of penalties for infringements) (http://eurlex.europa.eu/LexUriServ/LexUriServ.do?uri=OJ:L:2005:255:0011:002 1:EN:PDF) (20.02,.2010.)

28. (Regulation (EC) No 2099/2002 of the European Parliament and of the Council of $5^{\text {th }}$ November 2002 establishing a Committee on Safe Seas and the Prevention of Pollution from Ships (COSS) and amending the Regulations on maritime safety and the prevention of pollution from ships) (http://eur-lex.europa.eu/LexUriServ/LexUriServ.do?uri=0J:L:2002:324:0001:000 5:EN:PDF) (21.02,.2010.)

29. According to IMO "Conventions by Country" dated $25^{\text {th }}$ February 2010, USA ratified Annexes I,II,III,V and VI to MARPOL Convention, but not Annex IV dealing with stipulations with respect to pollution by ship's sew- age (http://www.imo.org/Conventions/mainframe. asp?topic_id=248) (21.02.2010)

30. US Coast Guard has the major role in investigations or inspections of ships. Moreover, it carries out testing, approval and issuance of certificates for marine sanitation devices in accordance with the types and standards of the US Coast Guard and Environmental Protection Agency.

31. Environmental Protection Agency sets and develops standards and regulations pertaining to pollution by ships.

32. Department of Justice takes lawsuits against offenders of federal laws, including those involved in marine pollution by ships.

33. This Act was brought by Environmental Protection Agency, Cruise Ship White Paper, United States Environmental Protection Agency, August 22, 2000.

34. The term Marine Sanitation Device refers to the device and equipment installed onboard, and designed to receive, keep, treat, process or discharge sewage waters.

35. No Discharge Zones (NDZ), can be approved by EPA under three conditions: a) if the environment requires better protection and if there are adequate reception facilities for sewage waters, b) special sea waters with particular importance for the environment, c) fresh water pumping of replenishment zones.

36. Source: Cruise Ship Discharge Assessment Report, Section 2: Sewage, United States Environmental Protection Agency, 29th December 2008, pp. 2-4.

37. Code of Federal Regulations, Title 33 - Navigation and Navigable Waters, Part 159 - Marine Sanitation Devices.

38. Source: Navigation and vessel inspection circular No.109, June 23, 2009, US Coast Guard. This provision is being implemented as of $1^{\text {st }}$ January 2010 , since implementation of IMO Resolution MEPC.159(55) Revised Guidelines on Implementation of Effluent Standards and Performance Tests for Sewage Treatment Plants, adopted on $13^{\text {th }}$ October 2006, implemented on device installed as of $1^{\text {st }}$ January 2010. (http://www.uscg.mil/ hq/cg5/nvic/pdf/2009/NVIC_1-09.pdf) (22.02.2010)

39. Code of Federal Regulations, 33 - Navigation and Navigable Waters, 159-Marine Sanitation Devices, Subpart E-Discharge of Effluents in Certain Alaskan Waters by Cruise Vessel Operations

40. Source: Subpart E-Discharge of Effluents in Certain Alaskan Waters by Cruise Vessel Operations, 159.309 Limitations on Discharge of Treated Sewage or Greywater.

41. AMSA is governmental organisation controlling the efficacy of safety and other services in Australian maritime industry. Organised and with competences similar to US Coast Guard.

42. Transport Operations (Marine Pollution) Regulation 2008 Subordinate Legislation 2008 No. 254 made under the Transport Operations (Marine Pollution) Act 1995, Volume 2, Queensland Government, (http://www.legislation.qld.gov.au/LEGISLTN/ SLS/2008/08SL254V2.pdf)

43. IMO MEPC 60/5/x1 Proposal to amend MARPOL $73 / 78$ Annex IV to include the possibility to establish special zones for the prevention of pollution by sewage and to designate the Baltic Sea as such Special 
Zone. The Baltic Sea is a closed sea with smaller salinity, where introduction of nutrients caused algal and plankton growth, production of organic matter and reduction of oxygen content, as well as disequilibrium of the ecosystem.

\section{LITERATURE}

Books:

[1] Milošević, B., Marine Environments and their Protection, Polytechnic of Dubrovnik, Dubrovnik, 1999

[2] Rudolf, D. International Maritime Law, JAZU, Zagreb, 1985

Articles in publication:

[3] Amižić Jelovčić, P. Pollution of Marine Environment by Ballast Waters With Particular Emphasis onto International Convention on Monitoring and Management of Ship's Ballast Waters and Sludge from 2004, Faculty of Law in Split Almanac, 4, Split 2008, pp. 797-810

[4] Barić Punda, V., The Role of the European Union in Protection and Preservation of the Mediterranean With Review of Some Legal and Strategic Documentation, Faculty of Law in Split Almanac, 4, Split 2008, pp. 761788

[5] Bupić, M., Milić, L., Ship's Sewage Treatment Plant With Reference to Venting and Clarification Procedures, Naše More 45 (3-4,5-6), Dubrovnik 1998

[6] Ćorić, D., Debeljak-Rukavina S., Protection of Marine Environment in Protected Ecological-Fishing Zone of the Republic of Croatia, Almanac of the Faculty of Law in Rijeka, Volume 29, No. 2, Rijeka, 2008, pp. 959-974

[7] Hanninen, S., Sassi, J., Estimated Nutrient load from waste waters originating from ships in the Baltic area updated 2009, Research report VTT-R-07396-08, VTT Technical Research Center of Finland, VTT, 2009

[8] West, A., Marine Pollution from Vessel Sewage in Queensland, Australian and New Zealand Maritime Law Journal, Vol. 18, Murdoch University, 2004, pp. 126-151

\section{Other sources:}

[9] Environmental Protection Act (Official Gazette, No. 110 / 07)
[10] Maritime Law (Official Gazette, No. 181/04, 76/07)

[11] Law on Croatian Register of Shipping (Official Gazette, No. 81/96)

[12] Rules on Protection of Marine Environment in Protected Ecological-Fishing Zone of the Republic of Croatia (Official Gazette, No. 47/08).

[13] Croatian Register, Rules for Statutory Certification of Seagoing Vessels Part 22 - Prevention from Pollution, 2009 (Official Gazette, No. 65 / 09).

[14] MARPOL Convention, (Official Gazette - International Conventions, No. 1/92, 4/05)

[15] United Nations Convention on Maritime Law, dated $10^{\text {th }}$ December 1982 (Official Gazette - International Conventions, No. 9/00)

[16] Convention on Protection of the Mediterranean from Pollution, Barcelona Convention (Official Gazette - International Conventions, No.12/93)

[17] Convention on Protection of the Marine Environment and Mediterranean Coastal Zone (Barcelona, 1995), (Official Gazette - International Conventions, No. 17/98)

Internet:

[18] UK Marine SACs Project, Possible Effects of High Concentration of Sewage Entering the Marine Environment from Recreational Craft, (http://www.ukmarinesac. org.uk/activities/ports/ph6_2_3.htm) (14.02.2010)

[19] IMO Resolution MPC.157(55) Recommendation on Standards for the Rate of Discharge of Untreated Sewage from Ships, adopted on $13^{\text {th }}$ October 2006, (http://www.imo.org/includes/blastDataOnly.asp/ data_id\%3D16315/157\%2855\%29.pdf) (21.02.2010)

[20] IMO Resolution MEPC.2(6) Recommendation on International Effluent Standards and Guidelines for Performance Tests for Sewage Treatment Plants, adopted on $3^{\text {rd }}$ December 1976 (http://www.imo.org/includes/ blastDataOnly.asp/data_id\%3D15319/2\%286\%29. pdf) (21.02.2010)

[21] IMO Resolution MEPC.159(55) Revised Guidelines on Implementation of Effluent Standards and Performance Tests for Sewage Treatment Plants, adopted on $13^{\text {th }}$ October 2006 (http://www.imo.org/includes/blastDataOnly.asp/data_id\%3D16317/159\%2855\%29.pdf) (21.02.2010) 